Sains Malaysiana 50(2)(2021): 515-523

http://dx.doi.org/10.17576/jsm-2021-5002-22

\title{
Image Reversal Resist Photolithography of Silicon-Based Platinum and Silver Microelectrode Pattern
}

(Fotolitografi Tahan Pembalikan Imej Silikon Berasaskan Corak Mikroelektrod Platinum dan Perak)

\author{
Nurulhaidah DaUd*, Nor Farhah RaZaK, Normahirah NeK AbD Rahman, AZIZAh Mohd Zahidi, Chin \\ Siew Xian, TengKu Elmi Azlina TengKu Muda\& Mohd Ismahadi Syono
}

\begin{abstract}
Silicon-based platinum (Pt) and silver (Ag) microelectrodes are constructed using photolithography technique and used in detecting arsenic activity in different electrolytes. Pt and Ag have good properties either as a working, a counter, or a reference electrode due to their low electrical resistance, high melting point, and high chemical stability. This chemical sensor has the ability to detect the changes in the level or activity of arsenic in electrolytes. Patterning these metals by wet chemical or dry etching is not a feasible process as these metals cannot be etched properly. The lift-off process can be applied to ease the etching process, but it has a major problem whereby the metal particles or ears may remain at the edges at the end of the process. The process variables, particularly the resist slope, were investigated to reduce possible defects using an image reversal resist. The thickness and angle of the resist side wall were measured by SEM. The effects of many factors that may influence or resist steep angle formation were analyzed and optimized with the Design of Experiment (DOE) technique to achieve the target recipe of resist angle $<60^{\circ}$. The lower angle of the resist side wall resulted in a better percentage yield of good electrode pattern after the lift-off process. The ability of fabricated microelectrode and influence of supporting electrolytes in arsenic determination were discussed.
\end{abstract}

Keywords: Lift-off; metal ear; photolithography; resist slope

ABSTRAK

Silikon berasaskan corak mikroelektrod platinum dan perak telah dibangunkan menggunakan teknik fotolitografi tahan pembalikan imej dan diuji dalam ujian awal dengan kitaran voltammetri. Membuat corak logam ini dengan bahan kimia basah atau kering bukanlah proses yang wajar kerana logam ini tidak dapat terukir dengan betul. Proses pengangkatan dalam fotolitografi dapat diaplikasikan untuk memudahkan proses pemunaran, tetapi ia mempunyai masalah besar kerana zarah logam atau telinga logam mungkin berada di tepi corak elektrod di akhir proses. Pemboleh ubah proses, terutamanya kemerosotan rintang dikaji untuk mengurangkan kemungkinan kecacatan menggunakan penentangan pembalikan imej. Ketebalan dan sudut dinding sisi rintang diukur dengan mikroskop elektron imbasan (SEM). Kesan daripada banyak faktor yang dapat mempengaruhi pembentukan sudut curam rintang dianalisis dan dioptimumkan dengan teknik Reka Bentuk Uji Kaji (DOE) untuk mencapai resipi sasaran sudut menolak $\leq 60^{\circ}$. Sudut bawah dinding sisi rintang menghasilkan hasil peratusan yang lebih baik bagi corak elektrod yang baik setelah proses mengangkat. Keupayaan mikroelektrik fabrikan dan pengaruh elektrolit pendukung dalam penentuan arsenik telah dibincangkan.

Kata kunci: Fotolitografi; logam telinga; pengangkatan; sudut penentangan

\section{INTRODUCTION}

In an electrochemical study, the use of integrated microelectrode offers several advantages such as a fast establishment of a steady-state signal and a decreased in IR; as current moves through a resistor, the voltage drops (Basri et al. 2015; Jasni et al. 2019). Planar microelectrode can be fabricated using the semiconductor fabrication technology with an integrated reference electrode and a working electrode, all mounted on a silicon base. The electrodes were independently connected to simultaneously indicate a redox reaction. Photolithography technique allowed the sensor size, number, and distribution of the 
plate to be individualized. The electrodes can be made from any material, but a suitable highly conductive inert material such as silver $(\mathrm{Ag})$ or platinum $(\mathrm{Pt})$ from the noble metal group is recommended (Hamdan et al. 2011; Karim \& Kamarudin 2013; Samad et al. 2018; Shaari \& Kamarudin 2019).

In photolithography technique, very often the metal has to survive the cleaning procedures and pre-treatment of wafers in an oxygen-rich environment before wafer bonding, as discussed by Firebaugh et al. (1998). A noble metal like Pt is hardly affected if subjected to one or more of these conditions. Pt or Ag metallization is difficult to pattern because of its high chemical stability. These noble metals are often used as the electrode material for sensor application, as discussed elsewhere (Çiftyürek et al. 2013; Jasni et al. 2019; Martinez-Quijada et al. 2013; Patel et al. 1996) and require proper adhesion with silicon or silicon/silicon dioxide $\left(\mathrm{Si} / \mathrm{SiO}_{2}\right)$ based adhesive (Basri et al. 2013; Desa et al. 2016).

There are two techniques that can be applied in photolithography, i.e. the 'etch-back' and the 'lift-off' techniques (Aziz et al. 2009; Hutagalung et al. 2014). Both techniques can be used to pattern thin films on surfaces. The lift-off method is applied where a direct etching of substrate material would have undesirable effects on the layer below and it is a suitable procedure for patterning two metals on one substrate. A challenge in the lift-off process is ensuring a clean separation between the metal film on the wafer substrate and the metal film on the resist. When the metal is deposited, it covers the side wall of the resist due to the positive slope of the positive photoresist. In this condition, the 'metal ears' can be formed along the side wall which will be standing upwards from the substrate surface or will fall over on the surface, causing an electrical shortcut with an opposite electrode or an unwanted shape on the substrate surface, respectively.

In this study, we used a lift-off technique with an image reversal resist and a negative mask is used rather than a positive to create a negative photoresist sidewall for higher resolution and improved lift-off. The method comprises of steps of applying an image reversal resist to a surface, performing a first pattern exposure of selected area using the first mask subsequent to the image reversal processing, developing the image reversal resist, depositing the metal layer, lift-off process, and repeated performing image reversal process for the next mask pattern until all the desired patterns are applied with no 'metal ears' problem.

Cyclic voltammetry (CV) is a powerful and common technique to study the behavior of reduction and oxidation processes of molecular species (Elgrishi et al. 2018). The redox process as in electrochemical studies is a good medium to study the behavior of fabricated electrode in targeted analyte solution by cycling the potential of a working Pt electrode and measuring the resulting current. Pt and Ag have good properties as electrode either as a working electrode, a counter electrode, or a reference electrode due to their low electrical resistance, high melting point, and high chemical stability (Karim \& Kamarudin 2013; Taer et al. 2011). The tested analyte, ferrocenium/ferrocene $\left(\mathrm{Fc}^{+} / \mathrm{Fc}\right)$ is often used as an internal standard for reporting electrode potentials. The test was done under assumption that the couple remains constant, regardless of the nature of the solvent (Gritzner \& Kůta 1984). In this study, we measured the redox couple of $\mathrm{Fc}^{+} / \mathrm{Fc}$ to determine and validate the initial capability of fabricated electrode with commercialized electrode from DropSense.

In the Design of Experiment (DOE) analysis, we strategically planned and executed experiments to study the effect of many factors that may influence the resist slope simultaneously, as well as the interaction effects.

\section{MATERIALS AND METHODS}

$4 \mu \mathrm{m}$ of thermal oxide was grown on a Si-based wafer. An image reversal positive photoresist layer (AZ5214E from Microchemicals, Germany) was applied on the silicon dioxide layer by a spin coater to form a thin film of resist. The mask was placed over the resist layer and was cured by exposing to ultraviolet (UV) light at $22.5 \mathrm{~mW} / \mathrm{cm}^{2}$ with SUSS MicroTec Mask Aligner and baked (prebake or reversal bake) on a hot plate at high temperature. The electrode pattern was then produced by a photolithography procedure. Another UV light exposure without a mask (flooded) was applied to make the unexposed resist in the first exposure soluble in the developer. After the developing process with AZ MIF 300 developer (AZ Electronic, USA), a thin film of platinum and silver was deposited by an e-beam evaporator (Evatec, Switzerland) with the metallization process in order to ensure against failure due to insufficient metal thickness. The photoresist layer was removed with acetone (SigmaAldrich, USA) supported by ultrasonic for $30 \mathrm{~min}$. If the metal ear is big, the defect can be visible under an optical microscope. The results of the lithography were examined and measured by scanning electron microscope (SEM). All results for DOE were analyzed by Minitab 16 Statistical software.

The electrode wafer was diced and built into Pt and Ag Echem with die attached and wire bond processes. Cyclic voltammetry experiments were performed with $\mu$ Autolab (Type III) (Microchemie) interfaced to a PC using Nova software for windows. Experiments were done in three-electrode system (Daud et al. 2012). The system consists of platinum pattern as working electrode, 
silver pattern as pseudo reference electrode and the third pattern is platinum auxiliary electrode. The solutions were deoxygenated by bubbling N2 gas through the solution for $15 \mathrm{~min}$ and N2 gas was allowed to flow freely over the surface of the solution during measurements (Daud et al. 2013; Yusof et al. 2011). The signal of Pt and Ag Echem and Pt and Ag from DropSense were measured using cyclic voltammetry $(\mathrm{CV})$ by scanning the potential from -0.5 to $+0.7 \mathrm{~V}$ with amplitude of $100 \mathrm{mV} / \mathrm{s}$ performed in each solution. All chemicals used were of analytical reagent grade. Aqueous solutions were prepared with deionized water.

\section{RESULTS AND DISCUSSION}

\section{FABRICATION OF ELECTRODE}

In the lift-off method, there are two types of resist coating: The positive and the negative resist coating. To reduce the metal ear (defect) after the lift-off process, an image reversal positive resist is needed. The recipe steps are different. The main advantage of using an image reversal positive resist is the angle of resist side wall. After developing the resist, the remaining resist will have a profile as shown in Figure 1. The best resist profile is the steepest inner slope. With an optimum recipe, a lower angle of resist sidewall can be achieved, and resist can be removed cleanly, leaving a well-defined metallization pattern behind and a higher percentage yield.

In the DOE analysis, two-level Fractional Factorial design, namely $2^{5-1}$, was chosen as the number of factors is more than 4 . The output of DOE, the resist angle, can be measured by a scanning electron microscope (SEM). The resist samples require a gold sputter coating before being measured with SEM to prevent charging of the resist. Observation of cross-section provides information about the thickness and angle of the resist layer on a wafer substrate. The parameters for half Factorial DOE on five factors are shown in Table 1.

By using a statistical analysis, the five factors were studied to find the relationship of each factor to achieve a negative side wall. The factors investigated are the spin coater rotation speed to achieve a suitable thickness of resist thin film on a substrate, the prebake temperature for resist before exposing with UV light, the UV light exposure time for the first and the second exposure, and the last factor is for the developing process in an alkaline solution. The output of the study is the resist angle by SEM. After the developing process, the samples were divided into small pieces, coated with a gold layer, and the cross-section was investigated by SEM. Results from the SEM study were analyzed by using a Minitab software. Figure 2 shows an interaction plot of the output study, which is the resist angle.
Based on Figure 2, the interaction term Coating*Prebake temp, Coating* UV exposure, Coating* flood exposure, UV exposure* flood exposure, UV exposure* develop time, and Flood exposure* develop time seem to have an interaction effect. The $R^{2}$ for all interaction factors is $86.95 \%(>80 \%)$, which is an acceptable value, and the $p$-value in the numerical analysis result suggests that they are significant. Figure 3 shows the main effect plot to achieve a lower resist angle in the lift-off recipe.

In Figure 3, the highest effect is on prebake temperature. Numerical analysis showed that prebake temperature factor has a $p$-value of $<0.10$. The result also shows that the most critical process in the image reversal (IR) process is the prebake temperature. Failure to optimize the prebake temperature will affect the resist profile the most. Once optimized, it must be kept constant within $\pm 1{ }^{\circ} \mathrm{C}$ to maintain a consistent process. If the chosen temperature is $>120^{\circ} \mathrm{C}$, the excessive baking will destroy the photoactive compound and reduce sensitivity (Škriniarová et al. 2017). The other part that has been exposed to a high temperature will remain thermally cross-linked with the resist, giving no pattern after the developing process.

Based on the data analysis, the 'Best' Factor level setting was determined. The 'Best' Factor level setting for all factors is at a low level. To achieve a lower angle, all parameters must be set at a low value. A confirmation run above the optimal set of conditions was conducted. The recipe was optimized until a suitable resist angle was achieved (angle $\leq 60^{\circ}$ ). Figure 4 shows a resist angle before and after optimization of the lift-off recipe.

Figure 3(A) shows a resist angle of $92.4^{\circ}$ and the thickness of resist is $2.19 \mu \mathrm{m}$. With this angle, the liftoff process cannot be done smoothly, and the effect of uncompleted liftoff can be seen in Figure 4(A). The side view of the pattern is easily peelabale and this can affect the surface area of sensitive electrode in $\mathrm{Pt}$ and $\mathrm{Ag}$ pattern on silicon substrate. Uneven surface area can give a nonuniform sensitivity when tested in voltammetry. The resulted thickness of the resist from this slope is too thin and the surface may tear apart and leave a defect shape of electrode pattern.

Before optimization, the best angle achieved by resist side wall slope is $92.4^{\circ}$ with a resist thickness of $2.19 \mu \mathrm{m}$. After optimization, the best angle achieved by resist slope is $40.2^{\circ}$ and the resist thickness is $4.34 \mu \mathrm{m}$. The slope gives a suitable peeling lift-off proses where we can see in Figure 4(B), the pattern of electrode can be acceptable with minimum tear along the edge. The resist is thick enough to prevent an unwanted peeling from the lift-off process. 
Based on DOE analysis, the best setting parameters are at a low level for all factors including the spin coater parameter. The lower rpm of resist coating will result in a higher thickness of resist layer, as shown in Figure 3(B). The flood exposure is given as long as sufficient energy is applied to make the unexposed areas soluble, hence the recipe was optimized to within 25-30 s of exposure time. The lower angle of resist side will also result in a good percentage yield of $\mathrm{Pt}$ and $\mathrm{Ag}$ pattern after lift-off as shown in Figure 5.

Based on sensors design, an 8 " silicon wafer $(20.32$ $\mathrm{cm}$ ) have maximum yield 220 sensors. After patterning process, a defect in metal ear and tear in metal pattern can be observed even with a naked eye. The different in defect yield before and after optimization process is $45 \%$. The percentage of good yield (clear pattern and no metal ear) before and after optimization is $65 \%$ (-143 sensors) and $84 \%$ (-185 sensors), respectively.

Further study should focus on validation process and optimization of ultraviolet (UV) exposure as the process can also affect the patterning process on resist surface. Grinding wafer process of silicon substrate could also attribute to the peel of pattern. Thus, further study in metal patterning process is needed to obtain a good, sensitive, reproducible and cost-effective electrode pattern.
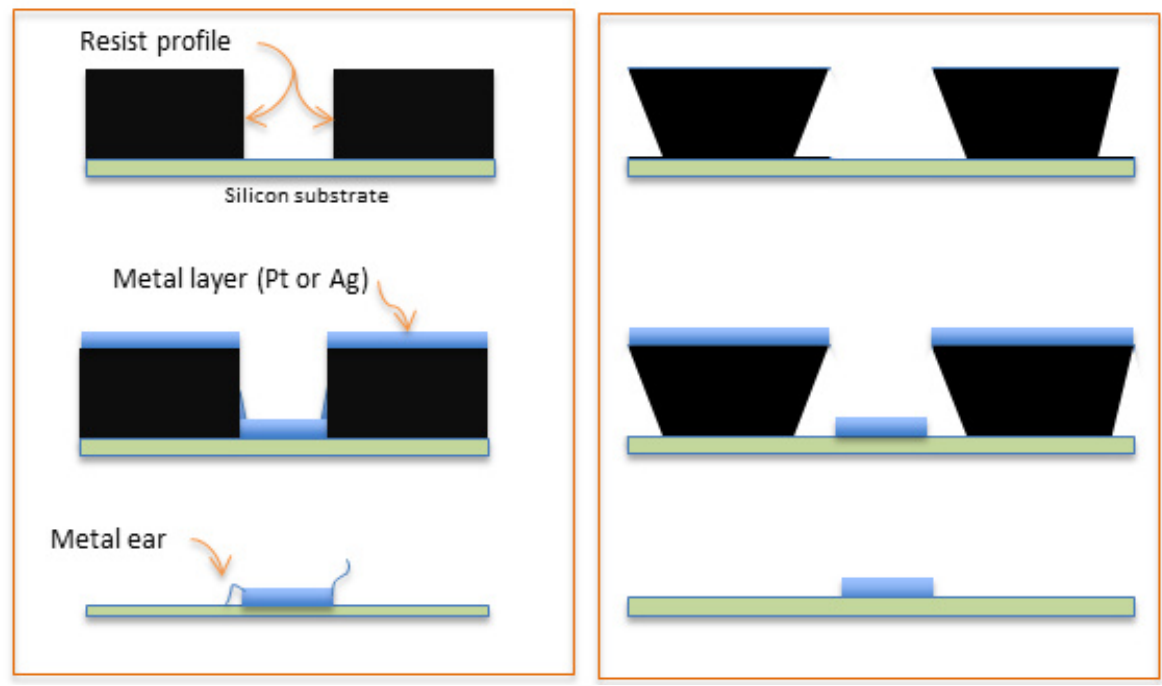

FIGURE 1. Resist profile for two different slope angles

TABLE 1. Parameters for half factorial of DOE on five factors

\begin{tabular}{ccc}
\hline \multirow{2}{*}{ Factors under study } & \multicolumn{2}{c}{ Factor levels } \\
\cline { 2 - 3 } & Low & High \\
\hline Spin coater rotation speed, rpm & 2500 & 3000 \\
Prebake temperature, ${ }^{\circ} \mathrm{C}$ & 110 & 120 \\
UV 1 $1^{\text {st }}$ exposure time, sec & 2.0 & 3.0 \\
UV Flood exposure time, sec & 38 & 58 \\
Develop time, sec & 90 & 120 \\
\hline
\end{tabular}



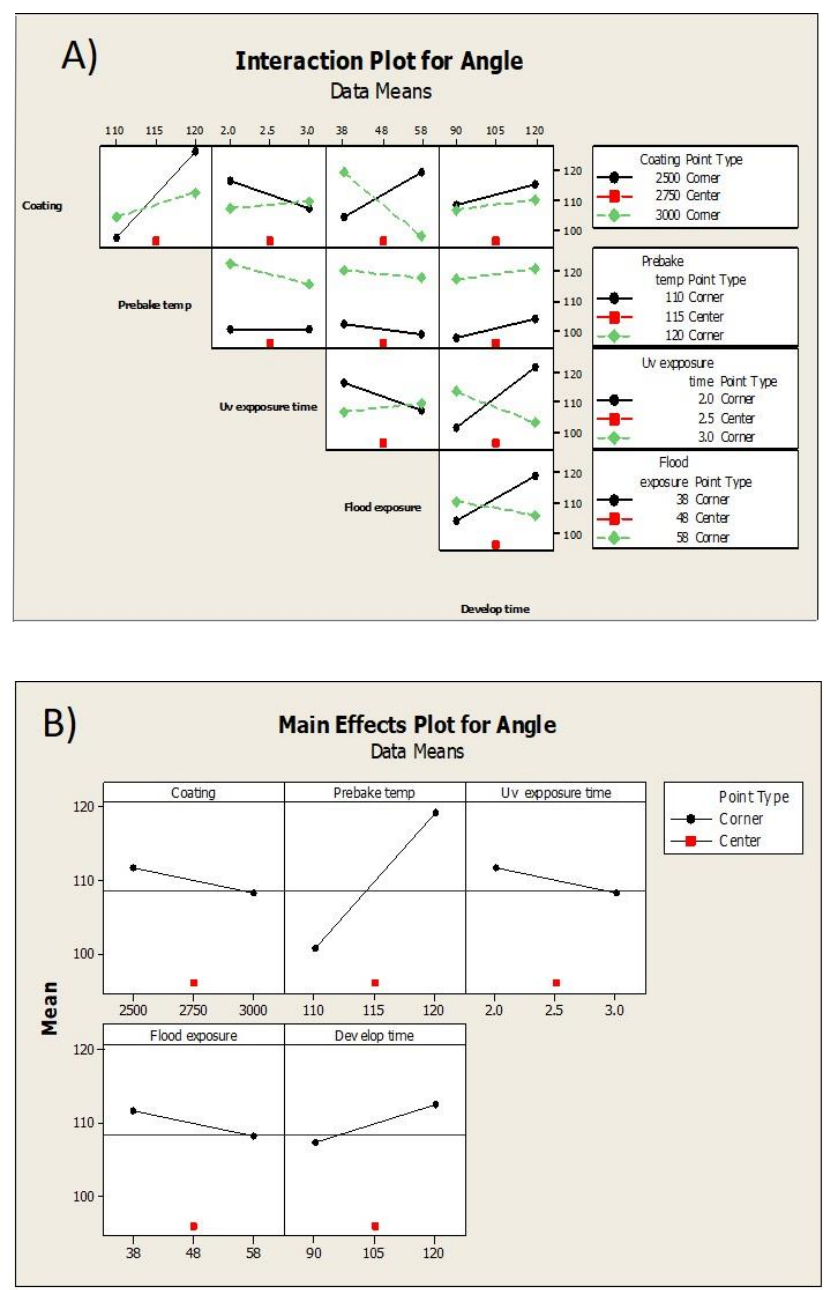

FIGURE 2. A) An interaction plot of the resist angle for 5 factors and B) main effect plot of resist angle for five factors

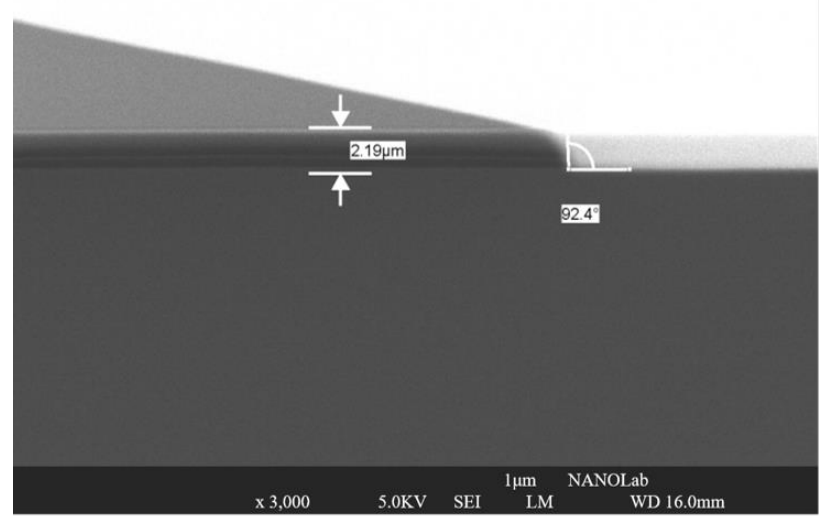

(A) 


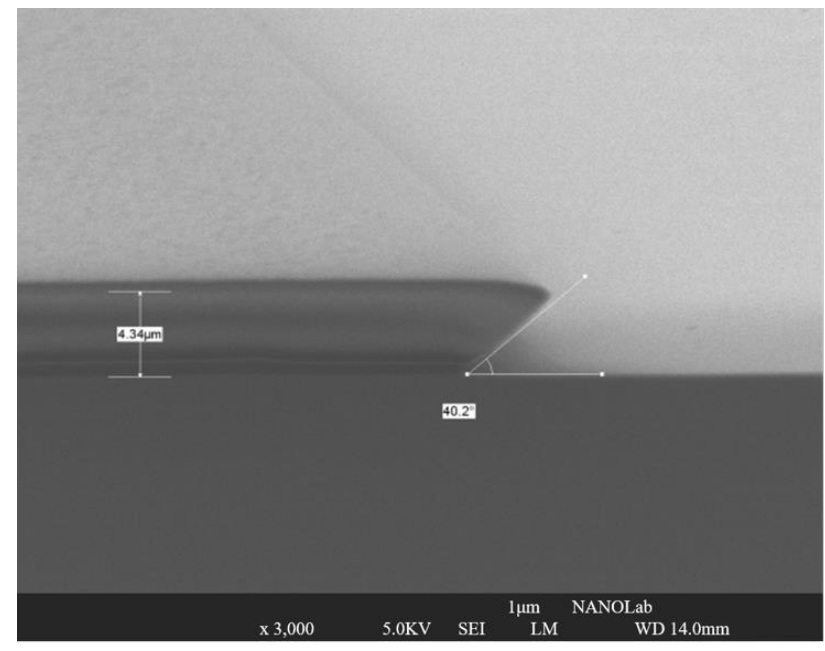

(B)

FIGURE 3. Cross-sectional view of SEM resist angle on silicon substrate, (A) before optimization and (B) after optimization process

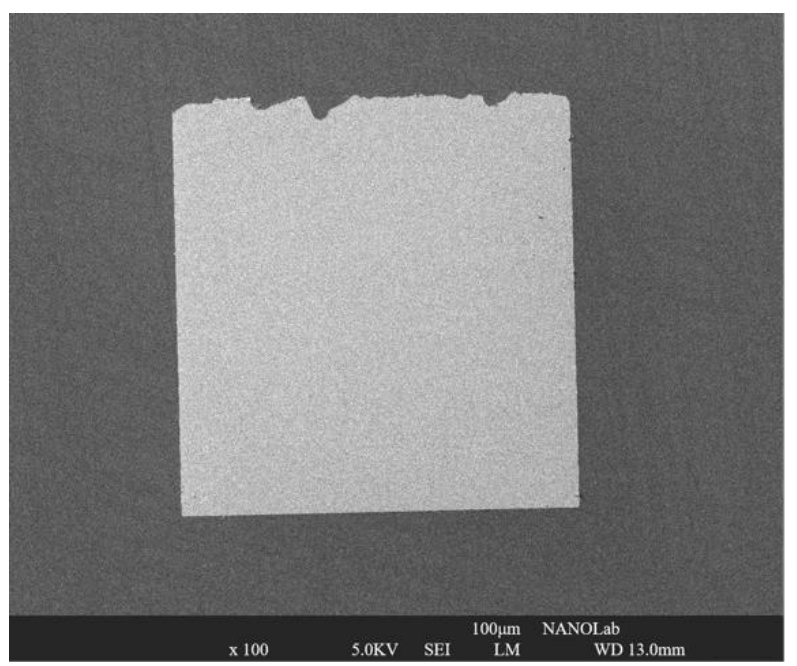

(A)

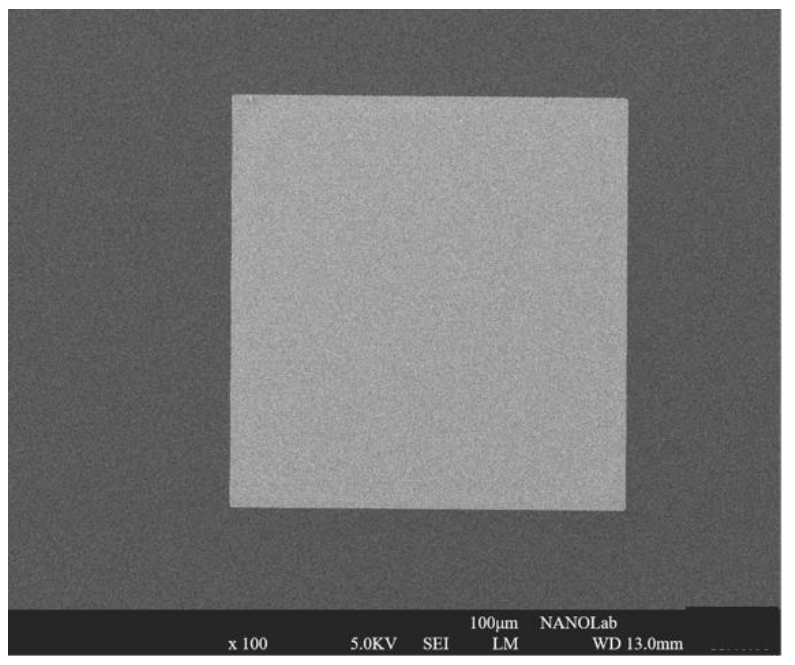

(B)

FIGURE 4. SEM surface of metal pattern on silicon substrate, (A) before optimization and (B) after optimization process 


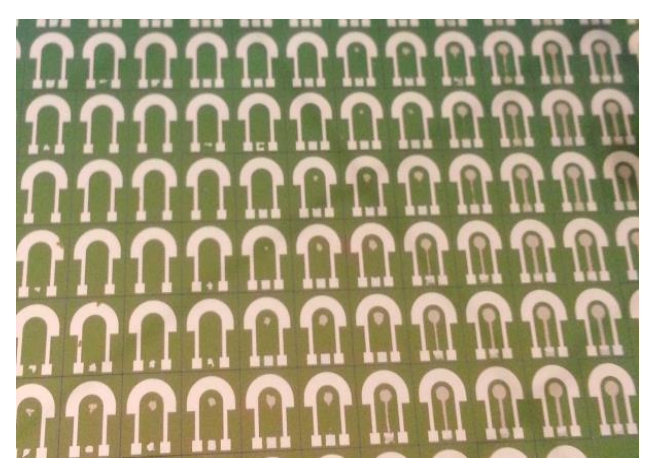

(A)

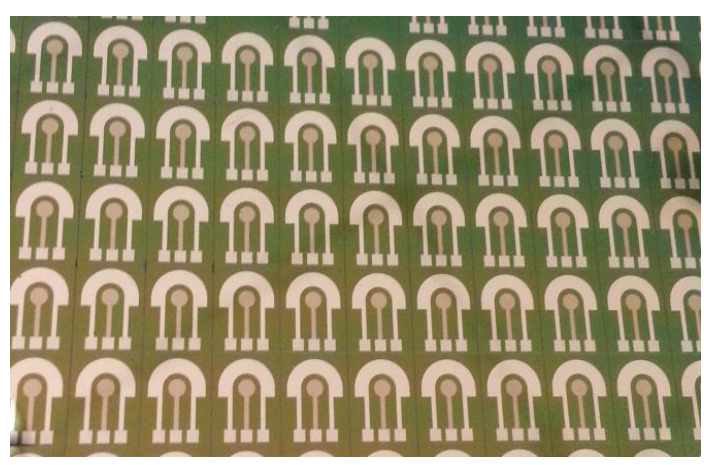

(B)

FIGURE 5. Pt and Ag pattern on silicon substrate after lift-off process (A) before optimization and (B) after optimization process

\section{CYCLIC VOLTAMMETRY MEASUREMENTS}

Cyclic voltammetry (CV) measurements were performed at the scan rates of $100 \mathrm{mV} / \mathrm{s}$ using the modified electrode in a redox couple consisting of $1 \mathrm{mM} \mathrm{K}_{3} \mathrm{Fe}(\mathrm{CN})_{6}$ in $1 \mathrm{M}$ $\mathrm{KCl}$ to explore the potential of fabricated electrode system in real-world electrochemical applications.

Figure 6 shows a redox reaction between fabricated $\mathrm{Pt}$ and $\mathrm{Ag}$ Echem electrode with commercialized Pt and Ag electrode from DropSense. A higher sensitive peak was obtained from our Pt and Ag Echem microelectrode when compared with DropSense. Both cycles are done in the same solution and condition.

The magnitudes of parameters were elucidated from the cyclic voltammogram including the anodic peak current, $\left(i_{\mathrm{pa}}\right)$, cathodic peak current $\left(i_{\mathrm{pc}}\right)$, anodic peak potential $\left(\mathrm{E}_{\mathrm{pa}}\right)$ and cathodic peak potential $\left(\mathrm{E}_{\mathrm{pc}}\right)$. Values in Table 2 differentiate the cathodic and anodic current value of graph in Figure 6. Based on data value, the Pt and Ag Echem produced higher sensitive current value compared to DropSense SPE.

Preliminary study of the voltammogram showed a highly current redox peak for Pt and Ag Echem suggested that this fabricated electrode has a higher sensitivity and comparable with DropSense electrode.

The peak currents increased highly for $\mathrm{Pt}$ and $\mathrm{Ag}$ Echem indicated that this electrode has a higher sensitivity and it is a good signal for a better electrode. Furthermore, a further characterization study is needed to confirm the ability of this fabricated electrode to behave as a good, sensitive and reliable electrode.

TABLE 2. Current height peak comparison of Pt and Ag Echem and commercial DropSense

\begin{tabular}{ccc}
\hline Peak height, A & Pt and Ag Echem & $\begin{array}{c}\text { DropSense SPE } \\
\text { (Commercial) }\end{array}$ \\
\hline Ipc & $1.65 \mathrm{e}-4$ & $8.39 \mathrm{E}-05$ \\
Ipa & $-1.3 \mathrm{e}-4$ & $-8.61 \mathrm{E}-05$ \\
\hline
\end{tabular}




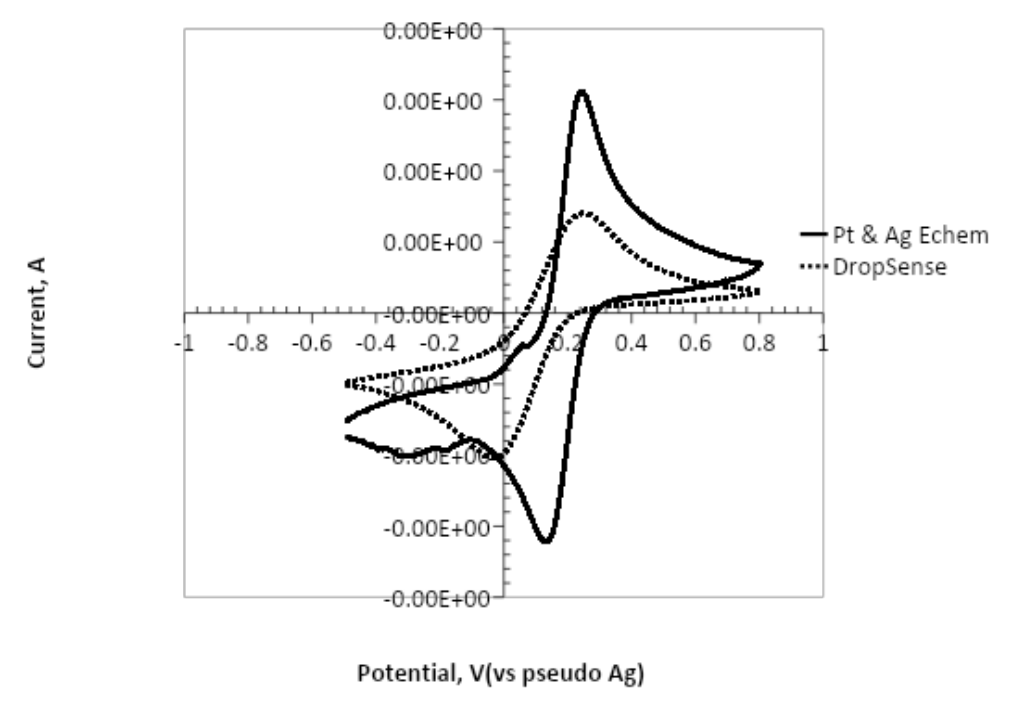

FIGURE 6. Cyclic voltammetry of Pt and Ag Echem and Dropsense SPE performances in $0.1 \mathrm{M} \mathrm{K}_{3} \mathrm{Fe}(\mathrm{CN})_{6}$ solution (IUPAC standard method)

\section{CONCLUSION}

The factors to achieve a lower angle of resist side wall have been studied using a DOE analysis. The thickness and angle of the resist side wall were measured by SEM method. The data were analyzed and optimized to achieve the target recipe of resist angle. The optimized recipe showed the capability to produce a good percentage yield of lift-off Pt and Ag electrode.

\section{ACKNOWLEDGEMENTS}

The author would like to acknowledge Fundamental Research Grant Scheme (FRGS/1/2019/STG01/ UKM/02/11), Geran Galakan Penyelidik Muda (GGPM2017-101) and the Ministry of Science, Technology and Innovation of Malaysia (Science Fund; 06-03-04SF0053) for funding this research.

\section{REFERENCES}

Aziz, N.A., Buyong, M.R. \& Majlis, B.Y. 2009. Process characterization of wet etching for high aspect ratio microneedles development. Advanced Materials Research 74: 341-344.

Basri, N.H., Deraman, M., Daik, R., Ayob, M.T.M., Sahri, M.I., Nor, N.S.M., Dolah, B.N.M. \& Soltaninejad, S. 2015. Electrochemical impedance spectroscopy study of supercapacitors using deposited nickel oxide nanoparticles carbon monolith electrodes. Advanced Materials Research 1112: 236-240.

Basri, N.H., Deraman, M., Kanwal, S., Talib, I.A., Manjunatha, J.G., Aziz, A.A. \& Farma, R. 2013. Supercapacitors using binderless composite monolith electrodes from carbon nanotubes and pre-carbonized biomass residues. Biomass and Bioenergy 59: 370-379.

Çiftyürek, E., Sabolsky, K. \& Sabolsky, E.M. 2013. Platinum thin film electrodes for high-temperature chemical sensor applications. Sensors and Actuators B: Chemical 181: 702714.

Daud, N., Yusof, N.A. \& Nor, S.M.M. 2013. Electrochemical characteristic of biotinyl somatostatin-14/nafion modified gold electrode in development of sensor for determination of $\mathrm{Hg}$ (II). International Journal of Electrochemical Science 8(7): 10086-10099.

Daud, N., Yusof, N.A., Tee, T.W. \& Abdullah, A.H. 2012. Electrochemical sensor for As(III) utilizing CNTs/leucine/ nafion modified electrode. International Journal of Electrochemical Science 7: 175-185.

Desa, M.M., Sapeai, S., Azhari, A.W., Sopian, K., Sulaiman, M.Y., Amin, N. \& Zaidi, S.H. 2016. Silicon back contact solar cell configuration: A pathway towards higher efficiency. Renewable and Sustainable Energy Reviews 60: 1516-1532.

Elgrishi, N., Rountree, K.J., McCarthy, B.D., Rountree, E.S., Eisenhart, T.T. \& Dempsey, J.L. 2018. A practical beginner's guide to cyclic voltammetry. Journal of Chemical Education 95(2): 197-206.

Firebaugh, S.L., Jensen, K.F. \& Schmidt, M.A. 1998. Investigation of high-temperature degradation of platinum thin films with an in situ resistance measurement apparatus. Journal of Microelectromechanical Systems 7(1): 128-135.

Gritzner, G. \& Kůta, J. 1984. Recommendations on reporting electrode potentials in nonaqueous solvents. Pure and Applied Chemistry 56(4): 461-466. 
Hamdan, M.S., Nordin, N. \& Amir, S.F.M. 2011. Electrochemical behaviour of $\mathrm{Ni}$ and Ni-PVC electrodes for the electroxidation of ethanol. Sains Malaysiana 40(12): 1421-1427.

Hutagalung, S.D., Lew, K.C. \& Darsono, T. 2014. Nanoscale patterning by AFM lithography and its application on the fabrication of silicon nanowire devices. Sains Malaysiana 43(2): 267-272.

Jasni, M.R.M., Deraman, M., Zainuddin, Z., Hua, C.C. \& Omar, R. 2019. Elektrod superkapasitor daripada komposit karbon teraktif dan grafen dengan perekat PVDFHFP. Sains Malaysiana 48(2): 407-417.

Karim, N.A. \& Kamarudin, S.K., 2013. An overview on non-platinum cathode catalysts for direct methanol fuel cell. Applied Energy 103: 212-220.

Martinez-Quijada, J., Caverhill-Godkewitsch, S., Reynolds, M., Gutierrez-Rivera, L., Johnstone, R.W., Elliott, D.G., Sameoto, D. \& Backhouse, C.J. 2013. Fabrication and characterization of aluminum thin film heaters and temperature sensors on a photopolymer for lab-on-chip systems. Sensors and Actuators A: Physical 193: 170-181.

Patel, S.V., DiBattista, M., Gland, J.L. \& Schwank, J.W. 1996. Survivability of a silicon-based microelectronic gas-detector structure for high-temperature flow applications. Sensors and Actuators B: Chemical 37(1-2): 27-35.

Samad, S., Loh, K.S., Wong, W.Y., Lee, T.K., Sunarso, J., Chong, S.T. \& Daud, W.R.W. 2018. Carbon and non-carbon support materials for platinum-based catalysts in fuel cells. International Journal of Hydrogen Energy 43(16): 7823-7854.

Shaari, N. \& Kamarudin, S.K. 2019. Recent advances in additive-enhanced polymer electrolyte membrane properties in fuel cell applications: An overview. International Journal of Energy Research 43(7): 2756-2794.
Škriniarová, J., Pudiš, D., Andok, R., Lettrichová, I. \& Uherek, F. 2017. Investigation of the AZ 5214E photoresist by the laser interference, EBDW and NSOM lithographies. Applied Surface Science 395: 226-231.

Taer, E., Deraman, M., Talib, I.A., Hashmi, S.A. \& Umar, A.A. 2011. Growth of platinum nanoparticles on stainless steel $316 \mathrm{~L}$ current collectors to improve carbon-based supercapacitor performance. Electrochimica Acta 56(27): 10217-10222.

Yusof, N.A., Daud, N., Tee, T.W. \& Abdullah, A.H. 2011 Electrocatalytic characteristic of carbon nanotubes/ glutamine/nafion modified platinum electrode in development of sensor for determination of As(III) International Journal of Electrochemical Science 6: 23852397

Nurulhaidah Daud*, Nor Farhah Razak, Normahirah Nek Abd Rahman, Azizah Mohd Zahidi, Chin Siew Xian \& Tengku Elmi Azlina Tengku Muda

Pusat GENIUS@Pintar Negara

Universiti Kebangsaan Malaysia

43600 UKM Bangi, Selangor Darul Ehsan

Malaysia

Mohd Ismahadi Syono

Nano Semiconductor Technology

Mimos Berhad, Technology Park Malaysia

57000 Kuala Lumpur

Malaysia

*Corresponding author; email: nurulhaidah@ukm.edu.my

Received: 27 July 2018

Accepted: 11 July 2020 